\title{
CONTRIBUICÕES DA NEUROLINGUÍSTICA DISCURSIVA PARA A COMPREENSÃO DO SUJEITO E DA LINGUAGEM NA SÍNDROME DO X-FRÁGIL
}

\author{
MICHELLI ALESSANDRA SILVA ${ }^{1}$ \\ (UNICAMP)
}

\begin{abstract}
RESUMO: Partindo da crítica de Coudry ([1986] 1988) sobre testes-padrão apresento uma reflexão sobre o discurso científico veiculado em diferentes publicações (artigos científicos, textos em sites de associações e entidades relacionadas à patologia, bem como em textos publicados em sites de eventos e conferências) sobre a Síndrome do X-Frágil com o intuito de analisar como essa patologia é descrita pela área médica, especialmente em relação ao desenvolvimento da linguagem, bem como quais efeitos de poder/saber (FOUCAULT, 2001) são produzidos por esse discurso e suas implicações. Para me contrapor ao discurso determinístico da área médica, apresento dados do processo de aquisição e uso da fala, leitura e escrita de um sujeito portador da síndrome acompanhado longitudinalmente destacando - com base nos pressupostos da Neurolinguística Discursiva - seu trabalho linguístico-cognitivo e as marcas de sua subjetividade na linguagem. A discussão dos dados procura, ainda, identificar em suas dificuldades linguísticas aquilo que pode ser patológico, o que faz parte do processo normal de aquisição e uso da fala/leitura/escrita e o que pode estar relacionado a outros fatores, que podem ser de ordem social ou relativos a história de vida do sujeito.
\end{abstract}

Palavras-chave: fala/leitura/escrita; neurolinguística discursiva; contradispositivos.

ABSTRACT: Starting from the Coudry's ([1986] 1988) of standard tests, I present a reflection on the scientific discourse from different publications (scientific articles, online texts from associations and organizations related to pathologies and also texts published in scientific events webpages and conferences) on the Fragile X Syndrome, to analyze how this pathology is described by the medical field, especially when it comes to language development and to the effects of power/knowledge (FOUCAULT, 2001) produced by this discourse and its implications. To counteract the deterministic discourse of the medical field, I present some data about the process of speech, reading and writing acquisition/use of one subject with the syndrome accompanied longitudinally highlighting - based on the assumptions of Discursive Neurolinguistics - his linguistic-cognitive work and the marks of his subjectivity in language. I attempt to identify these subject's language difficulties in order to point out what may be pathological, what is part of a normal speech, reading and writing acquisition/use and what may be related to other factors, which may be of a social order or related to the subject's life history.

Keywords: speech/reading/writing; discursive neurolinguistcs; counter-apparatus.

${ }^{1}$ Doutora em Linguística pelo Departamento de Linguística, do Instituto de Estudos da Linguagem (IEL), da Universidade Estadual de Campinas (UNICAMP), São Paulo, Brasil. e-mail: m.alessandra.silva@gmail.com. 


\section{INTRODUÇ̃̃O}

Após 30 anos do Diário de Narciso, a crítica aos testes-padrão como tarefas descontextualizadas continua necessária, por estes serem, infelizmente, ainda tão presentes na avaliação da linguagem e da capacidade cognitiva/intelectual de adultos e crianças. Buscarei discorrer sobre como os trabalhos de Coudry foram fundamentais para que caminhos alternativos fossem pensados e trilhados para incorporar o sujeito e a subjetividade nos estudos de linguagem nas patologias, mesmo nos casos muito particulares, como o de sujeitos com a Síndrome do X-Frágil. Para tanto, inicio resgatando um trecho do Diário de Narciso a esse respeito:

No caso dos sujeitos afásicos, o modo como eles têm sido tradicionalmente avaliados, revela sempre o ponto de vista de quem reproduz um sistema de regras e categorias fixas em que inexiste um lugar para o exercício subjetivo da linguagem. O afásico é sempre quem recebe os comandos do sistema e, nesse sentido, não passa pela experiência de constituir-se como locutor, perspectiva de quem produz um discurso sob a cobrança de uma "falta" sob o parâmetro do sistema (COUDRY, [1986] 1988, p.68)2.

Esse mesmo discurso que incide sobre a falta e a destaca também se aplica a crianças e adolescentes com ou sem patologias. Tendo isso em vista, apresento aqui uma reflexão sobre o discurso científico veiculado em diferentes publicações sobre a Síndrome do X-Frágil. Analiso como essa patologia é descrita pela área médica, especialmente em relação à linguagem, quais efeitos de poder/saber (FOUCAULT, 2001) são produzidos por esse discurso e suas implicações.

Também tomando como base o Diário de Narciso e, posteriormente, trabalhos nos quais Coudry teoriza sobre a aproximação entre afasia e infância (COUDRY, 2010a; 2012) - encontrando, nessa aproximação, caminhos paralelos para entender os processos de entrada e reentrada de afásicos e de crianças e adolescentes no mundo das letras (seja pela fala, seja pela leitura, seja pela escrita, seja pelo corpo, seja pela relação entre eles) - apresento alguns dados sobre o processo de aquisição e uso da fala, leitura e escrita de um sujeito diagnosticado como portador da síndrome do X-frágil, contrapondo minhas análises ao discurso médico.

\section{O CORPO COMO OBJETO DE ESTUDO}

Há um movimento, desde os primeiros estudos com a dissecação de animais, pela busca de indícios corporais que comprovem o que é observado nas ações e comportamentos humanos, principalmente para diagnosticar possíveis doenças e suas curas. O corpo humano, assim, tornou-se objeto de estudo, lugar e prova material das patologias (FOUCAULT, 2003).

${ }^{2}$ Em todas as citações, [1986] refere-se ao trabalho inicial de Coudry, sua tese de doutorado e 1988 ao ano de sua publicação como livro, com título homônimo. 
Como Coudry destacou em trabalhos que desenvolveu (COUDRY, [1986] 1988; 2007; 2009; 2010b; 2012), esse mesmo movimento vem acontecendo em relação às patologias (as que são de fato e as que não são) em que a linguagem está envolvida. Em trabalho anterior (SILVA, 2014) ${ }^{3}$, observei esse mesmo movimento em relação à avaliação da linguagem na Síndrome do X-Frágil (que será referida doravante como SXF), doença hereditária ligada ao cromossomo X, considerada a segunda etiologia genética de retardo mental - superada somente pela Síndrome de Down.

Segundo a literatura da área, a síndrome está relacionada à presença de uma região de fragilidade, mais sujeita a ocorrência de quebras ou falhas, localizada na porção distal do braço longo do cromossomo $\mathrm{X}$ - sítio frágil $[\mathrm{fra}(\mathrm{X})]$. $\mathrm{O}$ gene que se vincula ao fenótipo anômalo é designado FMR-1 (Fragile X Mental Retardation) e apresenta uma região de repetições de trinucleotídeos CGG que se torna instável. O produto do gene FMR-1 é uma proteína (FMRP) necessária para o desenvolvimento e função normais do cérebro, executando um papel essencial tanto na função sináptica como no crescimento dos dendritos (DARNEL et al., 2001, IRWIN et al., 2001).

Listo algumas das muitas características relacionadas ao quadro: dismorfismos faciais (face alongada e mandíbula proeminente), anomalias de pavilhão auricular (grandes e/ou em abano), palato alto, prega palpar única, estrabismo, autismo, hiperatividade, déficit de atenção, dificuldade de aprendizagem, dificuldade na interação social, contato visual escasso, timidez, ansiedade, movimentos estereotipados de mãos, atraso na aquisição de fala, ecolalia, distúrbios sintáticos, inconsistência no quadro fonético-fonológico, apraxia fonoarticulatória, entre outros (FUNDAÇÃO BRASILEIRA DA SÍNDROME DO X FRÁGIL, 2010).

Na caracterização da SXF o que se percebe é que todas as particularidades, enumeradas anteriormente sejam elas comportamentais, físicas, e associadas a outras patologias (Déficit de Atenção, Hiperatividade, Autismo), bem como possíveis dificuldades de linguagem, são descritas como sintomas da síndrome. Ao que parece, essa lista de sintomas compõe uma espécie de conhecimento sobre a doença que assegura que um determinado campo de saber tenha o poder de identificá-la e diferenciá-la de outras. Nesse sentido, o que está em foco é o valor atribuído a este conhecimento que pertence a um determinado campo de saber, ou seja, a medicina, e que define o que é ou não patológico a partir de características diversas, que juntas constituem o que Foucault chamará de estado. Em uma passagem de Os anormais, quando Foucault (2001) se refere ao caso Jouy, afirma:

(...) o que eles necessitam não é um processo, mas estigmas permanentes que marcam estruturalmente o indivíduo. (...) o ato e os estigmas se referem - um e outros, e de certo modo no mesmo plano, mesmo se sua natureza é diferente - a um estado permanente, a um estado constitutivo, a um estado congênito (FOUCAULT, 2001, p. 379).

${ }^{3}$ Projeto de Doutorado aprovado pelo Comitê de Ética em Pesquisa da Faculdade de Medicina da Universidade Estadual de Campinas - CEP: 988/2010. 
O estado congênito possibilita que a hereditariedade seja tomada como a origem do estado anormal, o que traz a esse campo de saber duas vantagens: (i) confere aos ancestrais a responsabilidade, por serem eles os transmissores do gene anômalo - referindo-se, assim, aos mecanismos anteriores de reprodução e colocando em suspenso a questão da sucessão familiar; (ii) e a possibilidade de que tudo pode ser causa da patologia. A noção de estado também traz vantagens a esse campo de saber, pois, por um lado, como vimos na descrição da síndrome, põe em relação qualquer elemento físico ou comportamento desviante, por mais díspares e distantes que sejam como se existisse uma espécie de fundo unitário que os explicasse; e, por outro lado, constrói um modelo fisiológico, isto é, um conjunto estrutural característico de um indivíduo, que ou teve seu desenvolvimento interrompido, ou regrediu de um estado de desenvolvimento ulterior a um anterior (FOUCAULT, 2001).

Nesse sentido, é preocupante a determinação que envolve a descrição de uma patologia. Para exemplificar, cito algumas afirmações de pesquisas sobre a SXF encontradas em artigos científicos, textos de sites de associações e entidades relacionadas à patologia, bem como em textos publicados em sites de eventos e conferências.

Em um estudo com 10 meninos portadores da SXF, com idades entre 6 e 13 anos, Yonamine e Silva (2002) caracterizaram, de acordo com suas palavras, "o nível de comunicação desses indivíduos a partir de escalas de desenvolvimento normal" (YONAMINE e SILVA, 2002, p. 981). Para a realização do estudo, as autoras dividiram os sujeitos em dois grupos "segundo a forma de comunicação: pré-linguística e linguística" (YONAMINE e SILVA, 2002, p. 984). Para aqueles que foram considerados como pré-liguísticos foi aplicada a lista de provas proposta pelo Protocol for the assessment of prelinguistic intentional communication e, para aqueles considerados como linguísticos, foi aplicado o Exame de Linguagem TIPITI. Como resultado, apresentam as seguintes conclusões:

Diante dos dados obtidos, confirma-se que pacientes com SXF apresentam notável atraso nos padrões de comunicação linguística, visto que se constatou que, entre a faixa etária de 6 e 13 anos, os indivíduos avaliados apresentaram comunicação pré-linguística ou linguística, até o nível de 3 anos. É importante o diagnóstico precoce que permita uma intervenção terapêutica o mais breve possível, além de se poder realizar a orientação familiar quanto aos aspectos genéticos o mais precocemente possível (YONAMINE e SILVA, 2002, p. 985).

Essas conclusões culminam em uma orientação que reforça o poder atribuído à hereditariedade no estado da doença: a indicação é para que a família e seus descendentes não tenham mais filhos. Há uma interdição do direito de gerar mais herdeiros, para que a patologia não se perpetue no corpo da família e da sociedade. E essa interdição, essa suspensão da sucessão familiar, não tem como função a prevenção ou a defesa de um grupo, mas a detecção, no interior desse grupo, de todos aqueles que poderão ser efetivamente portadores do perigo - seja de um estado, um estigma, um defeito, isto é, do não normal que trazem em si e que podem transmitir a seus herdeiros (FOUCAULT, 2001). 
As autoras apresentam ainda estudos que corroboram seus achados e citam que, em relação à evolução do QI, homens com a SXF demonstram declínio nos resultados, sendo o período mais marcante o início da puberdade (11 a 15 anos), sugerindo a existência de processo degenerativo contínuo (HODAPP et al., 1990; REISS; LEE; FREUND , 1994). Outros estudos (SPINELLI et al., 1995; SUKHALTER; MARANION; BROOKS, 1992) apontam que os indivíduos com SXF apresentam não apenas déficits relacionados à sintaxe, mas igualmente à semântica, como dificuldade de evocação de palavras e pouca habilidade em escolher a palavra correta do léxico mental, ao tentar produzir um pensamento com significado e bem estruturado.

Nessas afirmações encontra-se mais uma vantagem da qual o discurso da área médica usufrui. Ao referir que a nosografia dos estados anormais na psiquiatria se formulará na teoria da degeneração, Foucault afirma que:

(...) ela passa a ter uma possibilidade de ingerência indefinida nos comportamentos humanos. Mas, dando-se o poder de desconsiderar o doentio ou o patológico, e de relacionar diretamente o desvio das condutas a um estado que é ao mesmo tempo hereditário e definitivo, a psiquiatria se dá o poder de não procurar mais curar (FOUCAULT, 2001, p. 401-402)

É o que vemos como tendência nas afirmações dos estudos anteriormente citados. Ao considerar, nos casos de homens com a SXF, que há um declínio no QI e um processo degenerativo contínuo, ou ainda, que os níveis de comunicação de sujeitos com a síndrome chegam a ser equivalentes aos de uma criança de 3 anos de idade, o que resta a esse campo de saber? A possibilidade de cura ou mesmo de melhora torna-se sem sentido. Nessas afirmações destacam-se a falta, a insuficiência, o déficit.

A exemplo do que Coudry discute no Diário de Narciso (COUDRY, [1986] 1988), sobre as inadequações de procedimentos avaliativos e analítico-descritivos (incluindo baterias de testes-padrão) realizados pela afasiologia tradicional (em oposição ao que a Neurolinguística Discursiva propõe), essa visão revela uma concepção de desenvolvimento ${ }^{4}$ (estanque, com estágios delimitados) e de linguagem (a-histórica, como sinônimo de comunicação), pautada em um padrão estabelecido de normalidade, marcado linguisticamente: evolução do QI, níveis de comunicação, déficits relacionados à sintaxe e à semântica, comunicação pré-linguística e linguística. No mesmo sentido, as avaliações de linguagem utilizadas para classificar o sujeito são em sua maioria padronizadas, pautadas em atividades descontextualizadas, e comparam os resultados do sujeito portador de uma patologia que afeta o funcionamento cerebral (como é o caso da criança

\footnotetext{
${ }^{4}$ Assume-se, neste artigo, a concepção de desenvolvimento segundo Vygotsky (1998), entendido como um processo no qual se integram cultura e história. Tornam-se relevantes as situações concretas de vida, a linguagem e as relações de ensino. $\mathrm{O}$ autor destaca a importância da zona de desenvolvimento iminente (PRESTES, 2010) no processo de aprendizagem, considerando este processo não linear, e afirma que "o aprendizado desperta vários processos internos de desenvolvimento, que são capazes de operar somente quando a criança interage com pessoas em seu ambiente e quando em cooperação com seus companheiros" (VYGOTSKY, 1998, p. 100). Para Vygotsky, é pela mediação do outro e da linguagem que a criança gradativamente penetra em um universo de significações sociais e culturais, constituindo-se enquanto ser social e humano.
} 
ou do jovem com a SXF) com os de um sujeito sem patologia - concluindo dessa comparação que o anormal é o que se desvia do padrão e o normal o que é estabelecido como padrão, em geral baseado na gramática normativa e distante dos diversos usos da linguagem que o sujeito realiza. E são muitos os estudos que adotam essas ferramentas para avaliar, diagnosticar, classificar, rotular.

Em revisão de literatura, Ferreira e Lamônica (2005) constataram que a maioria dos estudos acerca da SXF usa testes psicométricos para medir o nível de inteligência dos sujeitos. As autoras verificaram que 12 dentre 15 estudos revistos usam protocolos padronizados para avaliar fala e linguagem. Nessa revisão, o WISC-R (Wechsler Intelligence Scale for Children-Revised) é apontado como um dos testes mais utilizados. Abaixo, apresento trechos de um subteste do WISC-R - vocabulário - que compõe parte do cálculo do desempenho e pontuação total da escala em relação à Compreensão Verbal 5 .

No subteste de vocabulário, a instrução é para que o teste seja interrompido após 5 fracassos consecutivos. O examinador deve dizer à criança: "Vou dizer algumas palavras. Escute-as atentamente e me diga o que significa cada palavra". Para cada palavra, o examinador deve perguntar: "O que significa...?" Segue-se uma lista de 32 palavras dentre as quais: faca, relógio, ladrão, burro, valente, chapéu, juntar, emigrar, alfabeto, rivalidade. São apresentados exemplos de respostas para cada palavra com as pontuações a serem atribuídas. Por exemplo, para a palavra relógio atribuem-se 2 pontos quando a criança responde "serve para ver a hora", "é um instrumento para medir o tempo"; atribui-se 1 ponto se a criança responde "tem ponteiros", "faz tic-tac", "tem a ver com o tempo", "é uma coisa redonda que me diz quando eu tenho que ir para a escola e quando eu tenho que voltar"; e não é considerado correto (ou seja, a pontuação é zero) quando a criança responde "fica pendurado na minha cozinha", "é uma coisa que dá voltas", "eu uso no pulso".

Testes como este deixam de considerar a relação do sujeito com a linguagem, a realidade em que vive e as possibilidades de trabalho criativo com a linguagem (FRANCHI, 1991). São testes que têm a pretensão de determinar o máximo de inteligência ou nível linguístico que uma criança pode atingir, a partir de uma visão restrita de língua e de suas variedades e que se distancia de seu funcionamento discursivo. Exemplo disso é o modo como abordam as palavras da língua, por meio de listas, ditados, repetições; como Coudry também pontua no Diário de Narciso (COUDRY, [1986] 1988). Consideram, ainda, possível mensurar o QI com base em respostas pré-definidas, que devem ser sempre as mesmas, como se uma determinada forma de expressão constituísse em si mesma o acesso ao potencial linguístico. Trata-se, portanto, de testes que determinarão as condutas escolares e terapêuticas a serem seguidas pelos profissionais. Sobre essa problemática, Moysés e Collares afirmam:

Na pretensão de acesso privilegiado à inteligência de uma outra pessoa através de tarefas padronizadas, descontextualizadas de sua vida, a Psicologia revela seus alicerces no campo da

${ }^{5}$ Para o cálculo total desse fator-Compreensão Verbal - são ainda considerados os desempenhos e pontuações dos subtestes Informação, Analogias e Compreensão. 
Clínica. Ao propor tarefas padronizadas a Clínica Psicológica silencia a criança, nega-lhe a voz para que não fale de si própria, de sua vida, não tenha a pretensão de ser sujeito. Também aqui, assim como na consulta médica, a relação entre dois sujeitos, pela pretensão da neutralidade e objetividade, é transformada em relação objeto-objeto. (MOYSES e COLLARES, 1997, p. 81-82).

Tal relação objeto-objeto não considera relevantes fatores não patológicos, que também afetam o sujeito - espaço geográfico e temporal, classe social, ou seja, as condições concretas de vida. E esse conhecimento assim sistematizado é impulsionado pelo poder a ele atribuído e veiculado. Um poder que determina o que é normal a partir de testes padronizados e que considera que tudo o que se desvia desse padrão é anormal ou patológico. Nessa prática, os processos são apagados e ficam apenas (supostos) sintomas.

\section{O CORPO A CORPO CONTRA OS DISPOSITIVOS}

A maneira como o corpo tem sido tomado como objeto de estudo, sobretudo pela área médica, tem produzido um excesso de patologização na infância, principalmente na criança em processo de escolarização (COUDRY, 2006, 2009, 2011; BORDIN, 2010; ANTONIO, 2011). E no caso de crianças com patologias de fato, tem impedido que elas aprendam efetivamente, uma vez que se parte do pressuposto de que são incapazes de aprender.

A Neurolinguística Discursiva incorpora a reflexão de Agamben (2009), que retomando o conceito de dispositivo de Foucault (1994), o define como "qualquer coisa que tenha de algum modo a capacidade de capturar, orientar, determinar, interceptar, modelar, controlar e assegurar os gestos, as condutas, as opiniões e os discursos dos seres viventes" (FOUCAULT, 1994, p. 41). Assim, entendo que o excesso de patologização, inclusive no interior das patologias, como é o caso da $\mathrm{SXF}$, funciona como um dispositivo que determina e captura o sujeito portador da SXF (processo de subjetivação), bem como orienta, controla e assegura as condutas, as opiniões e os discursos daqueles que fazem parte do entorno desse sujeito (familiares, educadores, fonoaudiólogos, entre outros). Como ensina Foucault, um dispositivo que condiciona saberes e práticas sobre a SXF.

Diante desse quadro o que sobra do/ao sujeito? Como propõe Agamben:

(...) a estratégia que devemos adotar no nosso corpo-a-corpo com os dispositivos não pode ser simples, já que se trata de nada menos que liberar o que foi capturado e separado pelos dispositivos para restituí-lo a um possível uso comum. É nesta perspectiva que gostaria agora de falar-lhes de um conceito sobre o qual me ocorreu de trabalhar recentemente. Trata-se de um termo que provém da esfera do direito e da religião romana (direito e religião estão, não somente em Roma, estreitamente conectados): profanação. (...) A profanação é o contradispositivo que restitui ao uso comum aquilo que o sacrifício havia separado e dividido (AGAMBEN, 2009, p. 14).

É preciso desenvolver práticas, portanto, que passem a funcionar como contradispositivos que atuem no corpo a corpo frente aos dispositivos que criam esse excesso de patologização (COUDRY, 2009, 2011; BORDIN, 2010; 
ANTONIO, 2011). Para tanto, o sujeito deve ser visto para além da patologia, ou seja, um sujeito histórico, que vive em um determinado tempo, em uma determinada cultura, sem o que não há possibilidade de linguagem.

\section{CAMINHANDO PELA NEROLINGUÍSTICA DISCURSIVA}

Acompanhei três portadores da SXF: PM (12 anos), AS (15 anos) e RC (19 anos) em sessões semanais individuais, com uma hora de duração (SILVA, 2014). $\mathrm{PM}$ e $\mathrm{AS}^{6}$ também eram acompanhados em sessões semanais em grupo no Laboratório de Neurolinguística (LABONE/IEL/UNICAMP). Ambos faziam parte do Centro de Convivência de Linguagens (CCazinho), grupo que tem como proposta acompanhar e compreender o processo de entrada no mundo da leitura e da escrita de crianças e jovens que receberam um diagnóstico (dificuldades de aprendizagem, dislexia, problemas no processamento auditivo, deficiência mental), que produz efeitos negativos em sua escolarização e em sua vida ${ }^{7}$.

A metodologia adotada é de natureza heurística e tem por fundamento o conceito de dado-achado, formulado por Coudry, "produto da articulação de teorias sobre o objeto que se investiga com a prática de avaliação e acompanhamento longitudinal de processos linguístico-cognitivos" (COUDRY, 1996, p. 183). Interpretar um fato como dado requer um método que nasce na prática clínica e que supõe dois tempos: o da ocorrência do fato na interlocução e o da análise do fato transformando-o em dado. $\mathrm{O}$ intervalo de tempo entre a constatação do que é um fato e sua transformação em dado pode ser maior ou menor, quase-simultâneo ou não. Esse tipo de dado é sempre revelador e encobridor de fenômenos linguísticos e sua análise proporciona o movimento teórico, permitindo a resolução de alguns problemas e a colocação de outros (COUDRY, 1996); daí a razão de um mesmo fato poder ser continuamente (re)interpretado, seguindo o curso da teorização. Procedimentos de descoberta são utilizados para compreender o que se apresenta, bem como para intervir nesse processo onde o dado-achado pode acontecer e ser flagrado.

Os pressupostos teóricos formulados pela Neurolinguística Discursiva (que será referida doravante como ND) ${ }^{8}$, que se fundamenta na variação funcional do cérebro determinada pela contextualização histórica dos processos linguísticocognitivos (VYGOTSKY, 1987; 1997; 1998; LURIA, 1981), se diferenciam radicalmente de uma visão de funcionamento cerebral médio e padrão para todos os falantes de uma língua natural. Nesse sentido, a ND se opõe à ideia de uma divisão estrita entre o que é da ordem do normal e do patológico, o que não

${ }^{6}$ AS ficou em acompanhamento individual de junho/2008 a julho/2010 e em grupo durante o período de Junho/2009 a junho de 2010.

${ }^{7}$ Para saber mais sobre o trabalho desenvolvido com esse grupo de crianças e jovens, ver Coudry, 2006, 2009 e Bordin, 2010.

${ }^{8}$ Para saber mais sobre a teorização na área da Neurolinguística Discursiva, consultar o capítulo Pressupostos Teóricos-Clínicos da Neurolinguística Discursiva, de Coudry e Freire (2010), no livro Caminhos da Neurolinguística Discursiva: teorização e práticas com a linguagem. 
significa que a patologia não exista: sempre que o aparelho cerebral for privado - por lesões congênitas e/ou adquiridas - de suas estruturas e funções, a patologia se estabelece (COUDRY; FREIRE, 2010). À ND interessa a relação heterogênea entre sujeito e linguagem e não uma relação pré-estabelecida entre a falta (para se atingir a normalidade) e a patologia; importam, assim, sujeitos comuns marcados por sua relação com a linguagem oral/escrita, práxis/corpo e percepção, e não sujeitos idealizados.

$\mathrm{Na}$ ND, são especialmente articulados a hipótese da historicidade e indeterminação da linguagem e os conceitos de trabalho e força criadora, formulados por Franchi ([1977] 1992). Benveniste (1972) e Jakobson (1972; 1975) são autores-âncora em relação aos conceitos de (inter)subjetividade e dos níveis de funcionamento da linguagem. Luria (1981) e Freud (1891) são incorporados por sua aproximação no que diz respeito ao funcionamento dinâmico e integrado de cérebro/mente, em que a linguagem está representada em todo o cérebro e não localizada em suas partes/centros. Também destacam-se os conceitos de dispositivo de Foucault (1994) e contradispositivos de Agamben (2009), mencionados anteriormente.

\section{CRIANDO CONTRADISPOSITIVOS}

Apresento, a seguir, alguns dados de um dos sujeitos acompanhados longitudinalmente, de forma a contrapor o que foi observado com o discurso determinístico da área médica.

\section{AS (15 ANOS)}

Diferentemente do contradiscurso (COUDRY, 2011; ANTONIO, 2011) que a ND se propõe a construir, observa-se no dado a seguir o tipo de conduta a que AS é exposto em sessão fonoaudiológica pautada em uma visão restrita de desenvolvimento e de linguagem que, conforme apresentado, encontra-se presente na literatura da área médica e, segundo nosso ponto de vista, mantém o sujeito na condição de incapaz de aprender a ler e escrever: 


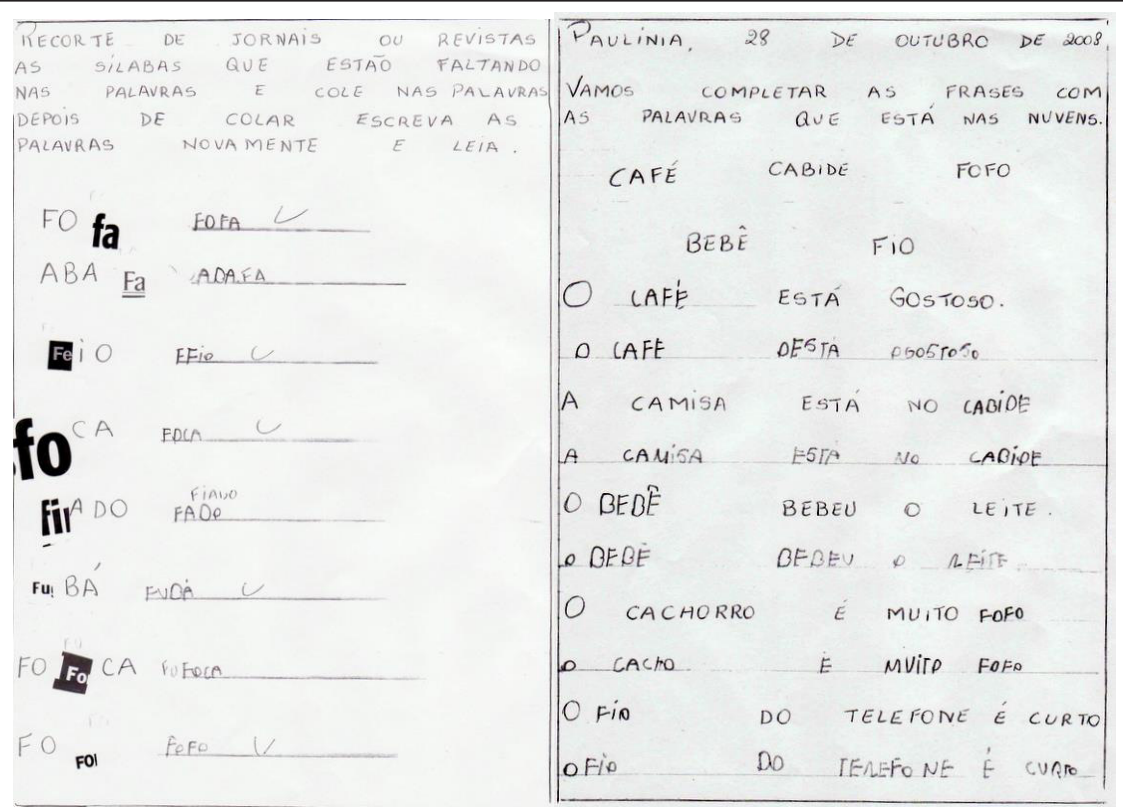

AS foi encaminhado para o CCazinho em junho de 2008, por apresentar dificuldade de concentração na escola e atraso na aquisição da leitura/escrita. Trata-se de filho de casal não consanguíneo, com antecedente de primo em primeiro grau materno com a SXF. Por essa razão, foi solicitado o exame genético de AS aos cinco anos de idade e descobriu-se que era portador da SXF (com 24\% de cromossomos com alteração). Frequentou uma escola especial e atualmente está matriculado na APAE da cidade onde reside. Seu irmão mais novo, hoje com seis anos de idade, também é portador da síndrome.

A mãe de AS relata que, na escola onde ele frequentava, eram sempre dados os mesmos conteúdos e exercícios. Os materiais escolares do jovem e os cadernos de todos os anos se pareciam muito e a atividade principal era sempre a cópia (sem sentido), como constata-se no Dado 1 apresentado. Em nosso primeiro contato, em agosto de 2008, na presença da mãe, pude notar que se tratava de um jovem extremamente tímido, que quase não falava e não olhava para seu interlocutor, ficando sempre cabisbaixo.

Seu corpo era tipicamente dócil (FOUCAULT, 1999) ou inerte (AGAMBEN, $2009)^{9}$. O tom de sua voz era quase inaudível - falava para dentro, curvava-se para

${ }^{9}$ Foucault (1999) menciona o termo corpo dócil ao fazer uma análise sobre o corpo do soldado do século XVIII. O autor, ao comparar o soldado do século XVII com a figura do soldado do século XVIII, o define como um corpo inapto, um corpo que se fabrica conforme as necessidades. Segundo Foucault, na época clássica o corpo foi descoberto como objeto e alvo de poder e, através da disciplina, pôde ser modelado e controlado. Como diz Foucault: "a disciplina fabrica corpos submissos e exercitados, corpos “dóceis"”. (FOUCAULT, 1999, p.127). Essa disciplina que "produz" corpos dóceis é uma forma de dominação. Refere-se a uma arte do corpo em que "o corpo humano entra numa maquinaria de poder que o esquadrinha, o desarticula e o recompõe. Uma 'anatomia política', que é também igualmente uma "mecânica do poder"” (FOUCAULT, 1999, p. 127), tornando este corpo 
dentro, era quase um prisioneiro de si mesmo. Essas são características apontadas nas descrições da síndrome - fazem parte da patologia, segundo a literatura, e, portanto, nunca foram objeto de intervenção. Sendo assim, não são consideradas passíveis de alteração. A exemplo do que se faz no CCazinho com as crianças sem patologias de fato, propus "mexer nesse corpo". Era preciso começar pelo corpo para trabalhar com a linguagem. Houve uma mudança significativa na fala e na atitude enunciativa desse sujeito depois que chamei a sua atenção para seu próprio corpo.

Em sessão individual, no dia 26/06/2008, abordando o tema das festas juninas que estavam acontecendo na época, sugeri a AS que fizéssemos uma lista de coisas de que precisaríamos para a festa. Coloquei alguns recortes que procuramos juntos em jornais e revistas com imagens que pudessem auxiliar na elaboração da lista. AS identificou alguns itens pertencentes às imagens expostas, porém demonstrou dificuldade em escrever seus nomes. Então, recorri ao jornal e a uma régua com o alfabeto escrito. Para escrever a palavra "bandeirinha", por exemplo, falava a sílaba inicial reforçando o som da primeira letra e perguntava com qual letra ele achava que começava e depois qual seria a próxima e assim por diante. Em muitos momentos, ele titubeou e não respondeu. Identificava com mais facilidade a vogal "a". Aos poucos, AS foi escrevendo as palavras que falava e foi identificando nas palavras que já havia escrito o som e as formas gráficas das palavras seguintes, com a minha ajuda. Nota-se, no Dado 2, que ao escrever "balão" há uma refacção: o "b" foi substituído por "p"; em "fogueira" aparece o "q" no lugar do "o" que, no entanto, antecede ao "g". São instabilidades ortográficas de letras que têm som e forma gráfica parecidos, comuns no início do processo de aquisição da escrita.

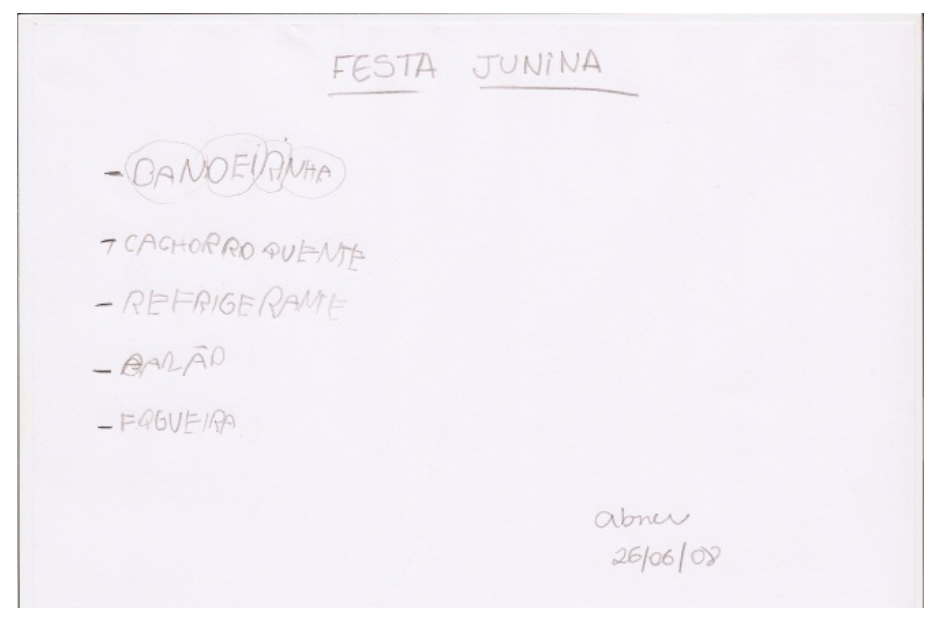

mais obediente e útil. Por meio desses métodos "coercitivos" disciplinares obtém-se assim o controle minucioso das operações corporais, sujeitando o indivíduo a uma espécie de relação de docilidade e utilidade - quanto mais dócil, mais útil se torna. O que Foucault (1999) formulou como corpos dóceis sujeitos a subjetivação, Agamben (2009) reinterpreta na contemporaneidade como "corpos inertes atravessados por gigantescos processos de dessubjetivação que não correspondem a nenhuma subjetivação real" (AGAMBEN, 2009, p. 15). 
A lista se resumiu a 5 palavras. No entanto, a tarefa durou aproximadamente 40 minutos. O fato de a tarefa ter levado tanto tempo não foi em função de uma lentidão ou falta de atenção de AS - muito pelo contrário, ele estava bastante empenhado em fazer a lista - mas da dificuldade em associar o som (sonoro/ motor) com a forma gráfica (motor/visual) das letras para formar as palavras que queria escrever.

Freud, em A interpretação das afasias (1891), propõe no estudo das afasias o aparelho de linguagem como um aparelho associativo; e faz isso se debruçando sobre o processo de como a criança entra para a fala, leitura e escrita. Segundo o autor, "aprendemos a falar associando a imagem sonora de palavra com a impressão da inervação da palavra" (FREUD, 1891, p. 87). Sendo assim, falar pressupõe associar a imagem sonora da palavra ouvida à impressão cinestésica/ inervação do aparelho motor da fala, com o objetivo de aproximar o som produzido do som ouvido - o que significa que para aprender a falar é preciso estar na relação com o outro. "Aprender a falar é aprender a repetir" (FREUD, 1891, p. 87), e é pela via do sentido, pela repetição/recordação do motor e do acústico da unidade funcional da palavra, e suas possíveis combinações, que o falante entra na língua onde funcionam e se articulam suas dimensões fonológica, sintática, semântica, pragmática. Como desdobramento disso tem-se que o já dito/ escrito pelo outro se torna o já ouvido/lido pela criança e nesse processo se dão novas cadeias associativas que colocam em relação o velho e o novo da língua (COUDRY, 2010a) $)^{10}$.

A relação entre o acústico e o motor se automatiza quando se pode ler mentalmente sem precisar do apoio da voz ou da escrita. Quando sabemos ler, o que é lido prescinde do visual implicado no traçado da letra - que já se automatizou para compor o sistema de representação alfabética de escrita e suas possibilidades combinatórias para formar unidades de sentido/significativas - a palavra (FREUD, 1891; SAUSSURE, 1978; VYGOTSKY, 2004; LURIA, 1981; BENVENISTE, 1972). Freud estabelece que o processo de ler com compreensão só se completa se houver reconhecimento da letra associado a um ou mais correspondentes acústicos, o que AS ainda não fazia. Ele tem dificuldade em manejar a concomitância entre o acústico, o motor e o visual, o que dificulta sua entrada no sistema alfabético. Precisa da soletração que segmenta a palavra e ainda não tem o retorno sonoro e motor do som da letra que, combinada com outras, formam a palavra.

A soletração, portanto, foi o caminho encontrado para que AS pudesse entrar na leitura e na escrita, para que a relação entre o sonoro/acústico, o motor e o visual começasse a ser construída. Como reflete Coudry, a partir da teorização de Freud:

Talvez a mais íntima relação entre letra e fala aconteça na soletração - que introduz sons novos para a criança (FREUD, 1891) - que é o primeiro passo para entrar no sistema alfabético: dizer o nome da letra selecionada, colocá-la sob as regras da escrita, combinando-a numa determinada

${ }^{10}$ A teorização de Freud (1891) - para entender o processo de entrada da criança no mundo da leitura e escrita - de base sonora, motora e visual, é incorporada pela ND nos trabalhos de Coudry (2006, 2009, 2010a, 2010b) e de Bordin (2010). 
sequência para formar uma palavra da língua, ao mesmo tempo em que é preciso apagar certos elementos que compõem o nome da letra para poder escrever a letra (não se escreve agá, mas $H$; nem eme, mas $M$ ). Para escrever bola a criança tem que manter o $b$, apagar o $e$ do nome da letra $b$, combiná-lo com a letra $o$, apagar o $e$ inicial e final do nome da letra ele e por fim juntar a letra $a$, caso contrário ficaria /beoelea/. Saber soletrar uma palavra significa escrevê-la mantendo certas letras e apagando outras, o que acaba se tornando automatizado - isso porque cerebralmente tantas vezes os neurônios percorrem um mesmo caminho que é facilmente recuperado, sem precisar pensar, o que corresponde ao encurtamento funcional descrito por Freud. É o que acontece ao ter aprendido a andar, falar, chutar bola, nadar. É importante destacar que soletrar é uma atividade metalinguística que incide sobre o escrever e não sobre a própria escrita porque não se escreve diretamente o que se soletra, mas há uma correspondência entre o nome e o som da letra e sua representação gráfica que é aprendida na vida escolar (COUDRY, 2010b, p. 11).

Podemos também observar no Dado 2 de AS que as instabilidades que apresentou na escrita $(\mathrm{b} / \mathrm{p}, \mathrm{q} / \mathrm{o} / \mathrm{g})$ indicam que ele conhece as similaridades acústicas e visuais que existem entre algumas letras, o que mostra que associações estão sendo feitas (LURIA, 1981; FREUD, 1891).

Destaco que AS, passou a identificar as letras e associar o som ao nome da letra e sua forma gráfica. Escreve palavras quando soletradas. No entanto, muitas vezes, ele altera a ordem das letras ou das sílabas quando copia algumas palavras, como aconteceu, por exemplo, na sessão individual do dia 04/09/08. Ao saber que AS tinha interesse por plantas, sugeri que planejássemos uma horta para ser feita em sua casa. Para tanto, consultamos uma revista sobre o assunto e fizemos uma lista das hortaliças que ele gostaria de plantar: um dos itens escolhidos foi cebola. Ao escrever a palavra, porém, AS escreveu "bcoela" e depois "bocela". AS tem dificuldade para (de)compor a palavra em seus elementos fonológicos e ordená-los; dificuldade em relação ao domínio da construção da palavra, o que afeta a ordem das letras e suas combinações (JAKOBSON, 1975). Porém, com a mediação do outro através da linguagem (explicando, apontado as diferenças, questionando, possibilitando associações) AS (re)escreve (VYGOSTSKY, 1997; 1998; 2004). Considere-se o Dado 3 seguinte, do dia 25/05/2010, em que AS copia da internet uma receita que ele, junto com a pesquisadora, fizeram para o grupo de crianças do CCazinho.

Devido ao seu interesse por culinária, na ocasião iniciávamos um caderno de receitas com as que haviam sido testadas e aprovadas por AS. A cópia, agora com sentido, levou 15 minutos para ser concluída. Durante o processo de escrita, AS perguntou sobre as diferenças de grafia entre algumas letras maiúsculas e minúsculas, o que mostra uma atitude de atenção (VYGOTSKY, 1997) frente ao que escreve, uma mudança em seu envolvimento com a leitura e escrita, que passa a ser um lugar de sentido, interesse e aprendizagem para esse sujeito, ao contrário do que sucedia em sua experiência anterior, na qual a escrita se revelava como uma tarefa repetitiva e sem sentido.

Essa mudança em AS provocou também uma mudança nas atitudes de sua mãe, que nos contou que seu filho lhe havia entregado um papel com nome e telefone de uma amiga que havia ligado em sua casa. Não acreditando ser possível que seu filho houvesse escrito o recado sozinho, não telefonou, mas guardou o 
número. No dia seguinte, resolveu ligar e, para sua surpresa, estava tudo correto. Como se trata de uma família em que há outros casos de portadores da SXF, a mãe de AS já tinha internalizado o discurso determinístico da área médica de que seu

\section{Cookies de Coco e Chocolate}

Ingredientes:

- 1/2 xícara de chá de manteiga

- 1/2 xícara de chá de açúcar

- $1 / 2$ xícara de açúcar mascavo

- 1 xicara de chá de farinha de trigo

1 xicara de chá de aveia

$100 \mathrm{~g}$ de coco ralado

2 ovos

colher de chá de bicarbonato de sódi

- $1 / 2$ colher de chá de baunilha

- Chocolate ao leite ou meio amargo em pedaços (o quanto desejar)

Modo de Preparo:

1. Misturar todos os ingredientes em um recipiente

Com a ajuda de uma colher, colocar pequenas porçôes da massa em uma

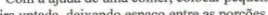

3. Levara ao forno quente por 12 a 15 minutos
CDOKIES DE COCOE CHDCOIATE

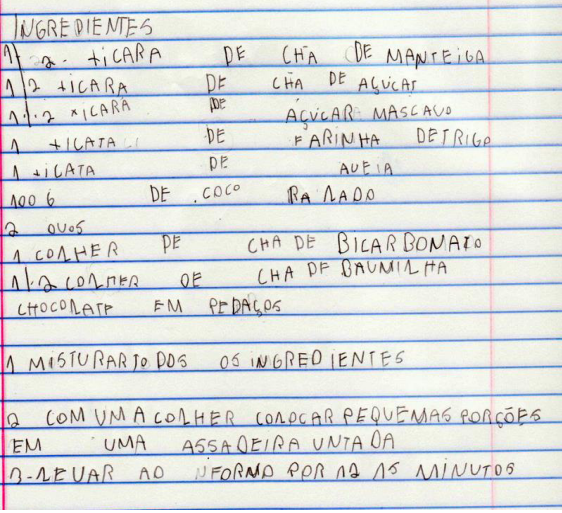

filho seria incapaz de realizar muitas coisas, como esta. Ao ver que seu filho era capaz, a mãe buscou outra instituição que possibilitou a profissionalização desse jovem, que hoje trabalha na panificadora modelo da escola onde estuda. É possível ver, assim, como os contradispositivos (AGAMBEN, 2009) são fundamentais para que até mesmo a criança com patologia de fato enfrente suas dificuldades e ultrapasse os obstáculos que o diagnóstico impõe.

\section{CONSIDERAÇÕES FINAIS}

Finalizo este trabalho, ressaltando uma das questões para as quais Coudry mais chama a atenção: a importância de se olhar o sujeito para além da patologia, focalizando sua relação com a linguagem em sua história de vida e em sua relação com o mundo e com o tempo em que vive. Busquei apresentar uma leitura crítica dos discursos hegemônicos e determinísticos da área médica sobre a SXF, com o intuito de questionar o que de fato é da ordem do patológico e o que são dificuldades que podem estar relacionadas a outros fatores, que podem ser de ordem social ou relativos à história de vida do sujeito.

No exercício do contradiscurso que a ND tem se proposto a construir foram apresentados dados de escrita produzidos pelo sujeito AS, no CCazinho, sinalizando uma forma de enfrentar os dispositivos que determinam o que é e o que não é da ordem da doença. Uma forma de enxergar possibilidades para além dos déficits e transtornos estabelecidos de antemão, para que as condutas 
terapêuticas e escolares não mantenham esse sujeito no lugar do não sentido, no lugar da impossibilidade de aprender.

Como ensina Brum (2006), é preciso mudar o olhar para rompermos com o vício e o automatismo de enxergar apenas o que é senso comum, o que nos programam para ver; a miopia do mundo que nos faz acreditar que somos ordinários ou incapazes. Um olhar que abarca, resgata, reconhece e, por isso, liberta.

\section{REFERÊNCIAS}

AGAMBEN, G. O que é o contemporâneo? E outros ensaios. Tradução de Vinícius N. Honesko. Chapecó, SC: Argos, 2009.

ANTONIO, G. D. R. Da sombra a luz: a patologização de crianças sem patologia. Dissertação Mestrado em Linguística - Instituto de Estudos da Linguagem da UNICAMP, 2011.

BENVENISTE, E. Problemas de Linguística Geral I. Tradução de Maria da Gloria Novak e Luiza Neri, São Paulo: Cia. Ed. Nacional e Ed. da USP, 1972.

BORDIN, S. M. S. Relatório do processo de inclusão no CCazinho (impresso), 2008.

BORDIN, S. M. S. Fala, leitura e escrita: encontro entre sujeitos. Tese Doutorado em Linguística Instituto de Estudos da Linguagem da UNICAMP, 2010.

BRUM, E. A vida que ninguém vê. Porto Alegre: Arquepelago, 2006.

COUDRY, M. I. H. Diário de Narciso: discurso e afasia. Tese de Doutorado. Instituto de Estudos da Linguagem, UNICAMP, 1986.

COUDRY, M. I. H. Diário de Narciso: discurso e afasia. São Paulo: Martins Fontes, 1988.

COUDRY, M. I. H. O que é dado em Neurolinguística? O método e o dado no estudo da linguagem. Maria Fausta C. Pereira de Castro (org.). Campinas: Editora da UNICAMP, p.179-194, 1996.

COUDRY, M. I. H. Linguagem e Afasia: uma abordagem discursiva da Neurolinguística. Cadernos de Estudos Linguísticos, 42, p.99-129, Jan/Jun, 2002.

COUDRY, M. I. H. Patologia estabelecida e vivências com o escrito: o que será que dá? Trabalho apresentado no $7^{\circ}$ Encontro Nacional sobre Aquisição da Linguagem (ENAL), 2006, publicado em CDROOM, Porto Alegre, 2007.

COUDRY, M. I. H. Despatologizar é preciso: a experiência do CCazinho. Anais do II Simpósio Mundial de Estudos de Lingua Portuguesa, Évora, p. 97-117, 2009.

COUDRY, M. I. H. Caminhos da Neurolinguística Discursiva: o velho e o novo. Caminhos da Neurolinguística Discursiva: teorização e práticas com a linguagem. Campinas: Mercado de Letras, 2010a.

COUDRY, M. I. H. Relatório de Pesquisa do Projeto Integrado em Neurolinguística: avaliação e banco de dados (impresso), 2010b. 
COUDRY, M. I. H; BORDIN, S. S. Afasia e Infância: registro do (in)esquecível. Cadernos de Estudos Linguísticos, v. 54 (1), p.135-154, 2012.

COUDRY, M. I. H.; FREIRE, F. M. P. Neurolinguística discursiva: teorização e prática clínica. Pressupostos teórico-clínicos da Neurolinguística Discursiva. Campinas: Mercado de Letras, 2010.

DARNEL, J. C. et al. Fragile X mental retardation protein mRNA targets harboring intramolecular G-quartets encode proteins related to synaptic function. Cell, 107, p.489-499, 2001.

FERREIRA, G. C.; LAMÔNICA, D. A. C. Caracterização da linguagem na síndrome do x-frágil: estudo bibliográfico. Pró-Fono Revista de Atualização Cientifica, v. 17, n. 1, jan-abr, 2005.

FOUCAULT, M. Le jeu de Michel Foucault. Dits et écrits III. Éditions Gallimard, 1994, p. 298 -329.

FOUCAULT, M. Vigiar e Punir: nascimento da prisão. Tradução de Raquel Ramalhete. Petrópolis: Vozes, 1999.

FOUCAULT, M. Os anormais: curso no Collège de France (1974-1975). Tradução de E. Brandão. São Paulo: Martins Fontes, 2001.

FOUCAULT, M. O nascimento da clínica. Tradução de R. Machado. $5^{\text {a }}$ ed. Rio de Janeiro: ForenseUniversitária, 2003.

FRANCHI, C. Criatividade e Gramática. Coordenadoria de Estudos e Normas Pedagógicas (CENP), São Paulo, 1991.

FRANCHI, C. Linguagem - Atividade Constitutiva. Cadernos de Estudos Linguísticos, 22, p. 9-39, [1977] 1992.

FREUD, S. A interpretação das afasias. Tradução de Ramón Alcalde. Buenos Aires: Ediciones Nueva Visión, 1891.

FUNDAÇÃO BRASILEIRA DA SÍNDROME DO X-FRÁGIL. Disponível em: www.xfrafil.com.br. Acesso em Setembro de 2010.

HODAPP, R.M. et al. Developmental implications of changing trajectories of IQ in males with fragile X syndrome. J Am Acad Child Adolesc Psychiatry, 29, p.214-219, 1990.

IRWIN, S. A. et al. Abnormal dendritic spine characteristics in the temporal and visual cortices of patients with fragile X syndrome. Am. J. Med. Genet., 98, p.161-167, 2001.

JAKOBSON, R. A afasia como um problema linguístico. Nova Perspectivas Lingüísticas. Miriam Lemle e Yonne Leite (orgs.). Petrópolis: Vozes, 1972.

JAKOBSON, R. Dois aspectos da linguagem e dois tipos de afasia. Linguística e comunicação. São Paulo: Cultrix, 1975.

LURIA, A R. Fundamentos de Neuropsicologia. São Paulo: EDUSP, 1981.

MOYSÉS, M. A. A.; COLLARES, C. A. L. Inteligência abstraída, crianças silenciadas: as avaliações de inteligência. Psicologia USP, São Paulo, v. 8, n. 1, p. 63-89, 1997. 
PRESTES, Z. R. Quando não é quase a mesma coisa: análise de traduções de Lev Semionovitch Vigotski no Brasil - repercussões no campo educacional. Tese de Doutorado. Faculdade de Educação da Universidade de Brasília, Brasília, 2010.

REISS, A. L.; LEE, J.; FREUND, L. Neuroanatomy of fragile X syndrome: the temporal lobe. Neurology, 44, p.1317-1324, 1994.

SAUSSURE, F. Curso de linguística geral. 2 ed. Tradução de Antonio Chelini et al. São Paulo: Cultrix, 1978.

VYGOTSKY, L. S. Pensamento e Linguagem. São Paulo, SP: Martins Fontes, 1987.

VYGOTSKY, L. S. Obras Escogidas. Tradução de Julio Guillermo Blank. Madrid: Visor, 1997 (Tradução espanhola dos originais russos de 1924 a 1934).

VYGOTSKY, L. S. A Formação Social da Mente. São Paulo, SP: Martins Fontes, 1998 (Tradução inglesa dos originais russos de 1934).

VYGOTSKY, L. S. Psicologia Pedagógica. São Paulo: Martins Fontes, 2004.

YONAMINE, S. M.; SILVA, A. A. Características da comunicação em indivíduos com a Síndrome do X-Frágil. Arquivos de Neuropsiquiatria, 60(4), p.981-985, 2002. 